\title{
Prevalence and distribution of Eimeria species in broiler chicken farms of different capacities
}

\author{
Adriana Györke*, Loredana Pop, and Vasile Cozma \\ Parasitology and Parasitic Diseases Department, Faculty of Veterinary Medicine, University of Agricultural Science and Veterinary \\ Medicine Cluj Napoca, 3-5 Calea Mănăştur, 400372 Cluj-Napoca, Romania
}

Received 11 June 2013, Accepted 28 November 2013, Published online 6 December 2013

\begin{abstract}
We conducted a survey in broiler farms from Romania to establish prevalence and distribution of Eimeria species using single PCR assay. We found Eimeria spp. in 21 (91\%) out of 23 flocks, and in $11(92 \%)$ out of 12 farms. Four species of Eimeria were identified: E. acervulina $(21 / 23 ; 91 \%)$, E. tenella $(14 / 23 ; 61 \%)$, E. maxima $(5 / 23 ; 22 \%)$ and E. praecox $(3 / 23 ; 13 \%)$. Infection with a single species (E. acervulina) was detected in $6(26 \%)$ infected flocks originated from large farms. Mixed infections were found in $15(65 \%)$ flocks and the most prevalent combination was $E$. acervulina + E. tenella $(8 / 23 ; 35 \%)$. Four flocks $(17 \%)$ harboured mixed infection with E. acervulina + E. tenella + E. maxima. E. acervulina was significantly more prevalent in flocks that received ionophores as anticoccidial feed additives.
\end{abstract}

Key words: Eimeria, Prevalence, Chicken, PCR, Romania.

\begin{abstract}
Résumé - Prévalence et répartition des espèces d'Eimeria dans les élevages de poulets de chair de capacités différentes. Nous avons mené une enquête dans les élevages de poulets de chair en Roumanie pour établir la prévalence et la répartition des espèces d'Eimeria en utilisant les tests PCR. Nous avons trouvé Eimeria spp. chez 21 $(91 \%)$ des 23 bandes de poules, et dans $11(92 \%)$ des 12 fermes. Quatre espèces d'Eimeria ont été identifiées : E. acervulina $(21 / 23 ; 91 \%)$, E. tenella $(14 / 23 ; 61 \%)$, E. maxima $(5 / 23 ; 22 \%)$ et E. praecox $(3 / 23 ; 13 \%)$. L'infection par une seule espèce (E. acervulina) a été détectée dans $6(26 \%)$ des bandes infectées provenant de grandes exploitations. Des infections mixtes ont été trouvées dans $15(65 \%)$ des bandes et la combinaison la plus fréquente était $E$. acervulina $+E$. tenella $(8 / 23 ; 35 \%)$. Quatre bandes $(17 \%)$ hébergeaient une infection mixte a E. acervulina $+E$. tenella $+E$. maxima. E. acervulina était significativement plus fréquente chez les bandes recevant des ionophores comme suppléments alimentaires anticoccidiens.
\end{abstract}

\section{Introduction}

Coccidiosis is one of the most important and costly diseases of poultry industry worldwide. The aetiological agents are apicomplexan protozoan parasites from Eimeria genus that multiply in the epithelial cells of the intestine. In poultry, there are seven recognized species that develop in certain parts of the gut (site-specific), each causing a separately recognizable disease [56]: E. acervulina, E. tenella, E. maxima, E. necatrix, E. mitis, E. praecox and E. brunetti. These species of Eimeria have different pathogenicity; E. tenella and E. necatrix are the most pathogenic and cause bloody lesions, high morbidity and mortality in naive chickens $[19,32]$; E. acervulina, E. maxima and E. brunetti also cause clinical diseases; E. praecox and

\footnotetext{
*Corresponding author: titilincua@yahoo.com
}

E. mitis, although considered to be relatively non-pathogenic [32], do cause a reduced feed conversion efficiency and growth rate [56]. Also, infection with certain species of Eimeria was demonstrated to be implicated in predisposing birds to necrotic enteritis [55], through lesions that compromise gut integrity, and allow the proliferation of pathogens [52].

Intensive chicken farming depends on specific prophylaxis of coccidiosis with in-feed anticoccidial drugs and live vaccines. Over time, the coccidiostats have become less effective due to development of drug resistance. Drug-resistant Eimeria strains are responsible for subclinical coccidiosis and, subsequently, for impaired economical performance as body weight gain, and feed conversion ratio [44]. The economic losses are significant, being estimated at more than 3 billion US\$ annually in the world [11], and the economic importance of subclinical 
Table 1. Species-specific primers targeting the ITS-1 region for Eimeria species that infect chickens*

\begin{tabular}{|c|c|c|c|}
\hline Species & Primer sequence $5^{\prime} 3^{\prime}$ & Annealing temperature $\left({ }^{\circ} \mathrm{C}\right)$ & Amplicon size (bp) \\
\hline \multirow[t]{2}{*}{ E. acervulina } & F 5'-GGGCTTGGATGATGTTTGCTG-3' & 65 & 145 \\
\hline & R 5'-GCAATGATGCTTGCACAGTCAGG-3' & & \\
\hline \multirow[t]{2}{*}{ E. brunetti } & F 5'-CTGGGGCTGCAGCGACAGGG-3' & 58 & 183 \\
\hline & R 5'-ATCGATGGCCCCATCCCGCAT-3' & & \\
\hline \multirow[t]{2}{*}{ E. maxima } & F 5'-GTGGGACTGTGGTGATGGGG-3' & 65 & 205 \\
\hline & R 5'-ACCAGCATGCGCTCACAACCC-3' & & \\
\hline \multirow[t]{2}{*}{ E. mitis } & F 5'-GTTTATTTCCTGTCGTCGTCTCGC-3' & 65 & 330 \\
\hline & R 5'-GTATGCAAGAGAGAATCGGGATTCC-3' & & \\
\hline \multirow[t]{2}{*}{ E. necatrix } & F 5'-AGTATGGGCGTGAGCATGGAG-3' & 58 & 160 \\
\hline & R 5'-GATCAGTCTCATCATAATTCTCGCG-3' & & \\
\hline \multirow[t]{2}{*}{ E. praecox } & F 5'-CATCGGAATGGCTTTTTGAAAGCG-3' & 65 & 215 \\
\hline & R 5'-GCATGCGCTAACAACTCCCCTT-3' & & \\
\hline \multirow[t]{2}{*}{ E. tenella } & F 5'-AATTTAGTCCATCGCAACCCTTG-' & 65 & 278 \\
\hline & R 5'-CGAGCGCTCTGCATACGACA-3' & & \\
\hline
\end{tabular}

* Primers previously described by Haug et al. [15] and Schnitzler et al. [40, 41].

coccidiosis varies with composition of coccidial populations [16]. Therefore, identification and genetic characterization of different species of Eimeria are central to prevention, surveillance and control of coccidiosis [31].

Identification of Eimeria species is based on clinical features, specific lesions in certain sites of the intestine, and morphological and biological features as sizes of oocysts, sites of infection, pre-patent period, sporulation time. Although, E. maxima can be easily identified based on oocyst size, while E. tenella and E. necatrix produce unmistakable lesions [14], identification through these parameters only is not always accurate due to overlapping characteristics [27]. Mixed infections are commonly found under field conditions, which pose a problem for the precise discrimination of species using classical methods. Moreover, classical methods are expensive, time-consuming [17] and require highly trained personnel [27].

Polymerase chain reaction (PCR) based assays proved to be effective for identification of all seven species of Eimeria in chickens. The used target regions are small subunit rRNA [48], 5S rRNA [46], first and second internal transcribed spacers (ITS-1; ITS-2) of nuclear ribosomal DNA [13, 15, 40], and sequence-characterized amplified region (SCAR) derived from random amplified polymorphic DNA (RAPD) profiles [12].

We conducted a survey in broiler chicken farms in Romania from August to November 2010. The aim was to establish the prevalence and distribution of Eimeria species by PCR in different size broiler farms with different prophylactic programmes.

\section{Material and methods}

\section{Broiler industry in Romania}

Union of poultry breeders from Romania has 276 members, of which 18 large poultry companies that produce over 10 thousand tons of meat/year/farm, 22 medium poultry companies that produce between 5 and 10 thousands tons of meat/year/farm and 236 small poultry companies that produce less than 5 thousands tons of meat/year/farm [49]. The production of poultry meat in 2010 was about 317 thousands tons. Average performances in the same year were: daily body weight gain $54.19 \mathrm{~g}$; feed conversion ratio of 1.859 ; mortality of $4.24 \%$; and European Production Index 299.15 [49].

The most common broiler breeds are Cobb500 and Ross308, and they are reared in houses made of concrete on wood shavings. Prophylaxis of coccidiosis is based on the use of in-feed anticoccidial drugs.

The average age at slaughter is about 42 days, and average live weight of $2.2 \mathrm{~kg}$. The time between successive grow-outs is about 2-3 weeks. Used litter is removed and the broiler houses are cleaned and chemically disinfected.

\section{Study flocks and samples}

The study was conducted in 12 broiler farms from Romania picked by simple random sample, during August-November 2010. Farms were subsequently divided according to their size in three groups: small $(n=4)$, medium $(n=3)$ and large $(n=5)$ farms. Prophylaxis of coccidiosis was made with different ionophores and chemicals as it is stated in Table 1.

We collected faeces samples from 2 flocks/farm, except farm " $D$ ", in total 23 flocks, when chickens were 20-35 days old (median 28 days), and information regarding coccidiostat drugs used (Table 2). Approximately $250 \mathrm{~g}$ of fresh faecal droppings/sample was collected at random by hand along the feed and water lines. The samples were processed once they arrived in the laboratory by flotation method with saturated sodium chloride (specific gravity $1.18-1.2$ ) and stored at $4{ }^{\circ} \mathrm{C}$ till the next day. Afterwards, oocysts were isolated, purified and concentrated from faeces with saturated salt solution [43] and sporulated in $2.5 \%$ potassium dichromate solution. The oocysts were washed free from the salt and potassium dichromate by repeated centrifugation and resuspended in tap water. At the end, molecular analysis was done by PCR in order to identify the species of Eimeria. 
Table 2. List of field samples and the results of ITS-1 PCR.

\begin{tabular}{|c|c|c|c|c|c|c|c|c|c|c|}
\hline Farm & Flock & Age (days) & Coccidiostat $^{\mathrm{a}}$ & Total & E. acervulina & E. tenella & E. maxima & E. praecox & Single infection & Mixed infections \\
\hline \multicolumn{11}{|c|}{ Small-size farms (8 flocks) } \\
\hline A & 1 & 28 & Lasalocid (Avatec) & + & + & + & - & - & - & $+(\mathrm{A}+\mathrm{T})$ \\
\hline A & 2 & 32 & Lasalocid (Avatec) & + & + & + & - & - & - & $+(\mathrm{A}+\mathrm{T})$ \\
\hline $\mathrm{F}$ & 1 & 30 & Lasalocid (Avatec) & + & + & + & - & + & - & $+(\mathrm{A}+\mathrm{T}+\mathrm{P})$ \\
\hline $\mathrm{F}$ & 2 & 26 & Lasalocid (Avatec) & + & + & + & - & - & - & $+(\mathrm{A}+\mathrm{T})$ \\
\hline $\mathrm{K}$ & 1 & 25 & Maduramycin (Cygro) & + & + & + & - & - & - & $+(\mathrm{A}+\mathrm{T})$ \\
\hline $\mathrm{K}$ & 2 & 25 & Maduramycin (Cygro) & + & + & + & - & - & - & $+(\mathrm{A}+\mathrm{T})$ \\
\hline $\mathrm{L}$ & 1 & 28 & nd & + & + & + & + & - & - & $+(\mathrm{A}+\mathrm{T}+\mathrm{M})$ \\
\hline $\mathrm{L}$ & 2 & 25 & nd & + & + & + & + & + & - & $+(\mathrm{A}+\mathrm{T}+\mathrm{M}+\mathrm{P})$ \\
\hline Total $n(\%)$ & & Med. $=27$ & & $8(100)$ & $8(100)$ & $8(100)^{* *}$ & $2(25)$ & $2(25)$ & 0 & $8(100)^{*}$ \\
\hline \multicolumn{11}{|c|}{ Medium-size farms (6 flocks) } \\
\hline B & 1 & 29 & Narasin + nicarbazin (Maxiban) & + & + & + & - & - & - & $+(\mathrm{A}+\mathrm{T})$ \\
\hline B & 2 & 29 & Narasin + nicarbazin (Maxiban) & + & + & + & + & - & - & $+(\mathrm{A}+\mathrm{T}+\mathrm{M})$ \\
\hline $\mathrm{C}$ & 1 & 20 & Diclazuril (Clinacox) & - & - & - & - & - & - & - \\
\hline $\mathrm{C}$ & 2 & 32 & Diclazuril (Clinacox) & - & - & - & - & - & - & - \\
\hline G & 1 & 29 & Monensin (Coxidin) & + & + & + & - & - & - & $+(\mathrm{A}+\mathrm{T})$ \\
\hline G & 2 & 29 & Monensin (Coxidin) & + & + & + & - & - & - & $+(\mathrm{A}+\mathrm{T})$ \\
\hline Total $n(\%)$ & & Med. $=29$ & & $4(66,7)$ & $4(66,7)$ & $4(66,7)$ & $1(16,7)$ & 0 & 0 & $4(66,7)$ \\
\hline \multicolumn{11}{|c|}{ Large-size farms (9 flocks) } \\
\hline $\mathrm{D}$ & 1 & nd & Robenidine(Cycostat) & + & + & - & - & - & $+(\mathrm{A})$ & - \\
\hline $\mathrm{E}$ & 1 & 28 & Salinomycin (Sacox) & + & + & - & - & - & $+(\mathrm{A})$ & - \\
\hline $\mathrm{E}$ & 2 & 27 & Salinomycin (Sacox) & + & + & - & - & - & $+(\mathrm{A})$ & - \\
\hline $\mathrm{H}$ & 1 & 28 & Diclazuril (Clinacox) & + & + & - & - & + & - & $+(\mathrm{A}+\mathrm{P})$ \\
\hline $\mathrm{H}$ & 2 & 35 & Diclazuril (Clinacox) & + & + & - & - & - & $+(\mathrm{A})$ & - \\
\hline I & 1 & 28 & nd & + & + & - & - & - & $+(\mathrm{A})$ & - \\
\hline I & 2 & 28 & nd & + & + & - & - & - & $+(\mathrm{A})$ & - \\
\hline $\mathrm{J}$ & 1 & 35 & Monensin (Coxidin) & + & + & + & + & - & - & $+(\mathrm{A}+\mathrm{T}+\mathrm{M})$ \\
\hline $\mathrm{J}$ & 2 & 28 & Monensin (Coxidin) & + & + & + & + & - & - & $+(\mathrm{A}+\mathrm{T}+\mathrm{M})$ \\
\hline Total $n(\%)$ & & Med. $=28$ & & $9(100.0)$ & $9(100.0)$ & $2(22.2)$ & $2(22.2)$ & $1(11.1)$ & $6(75.0)^{* *}$ & $3(33.3)$ \\
\hline Total $n(\%)$ & $n=23$ & Med. $=28$ & & $21(91,3)$ & $21(91.3)^{* * *}$ & $14(60,9)$ & $5(21,7)$ & $3(13,0)$ & $6(26.1)$ & $15(65,2)^{* *}$ \\
\hline \multicolumn{4}{|c|}{ Ionophores $(n=14)$} & $14(100)^{*}$ & 14(100)* & $12(85.7)^{* *}$ & $3(21.4)$ & $1(7.1)$ & $2(14.3)$ & $12(85.7)^{*}$ \\
\hline \multicolumn{4}{|c|}{ Chemicals $(n=5)$} & $3(60)$ & $3(60)$ & 0 & 0 & $1(20.0)$ & $2(40.0)$ & $1(20.0)$ \\
\hline
\end{tabular}

${ }^{a}$ Nineteen out of 23 farmers answered to question regarding the coccidiostat used in-feed for coccidiosis control. $\mathrm{A}=E$. acervulina; $\mathrm{T}=E$. tenella; $\mathrm{M}=E$. maxima; $\mathrm{P}=$ E. praecox. + positive; - negative. Fisher exact test: ${ }^{*} p<0.05 ; * *<0.01 ; * * p<0.001$. nd $=$ not done; Med. $=$ median. 


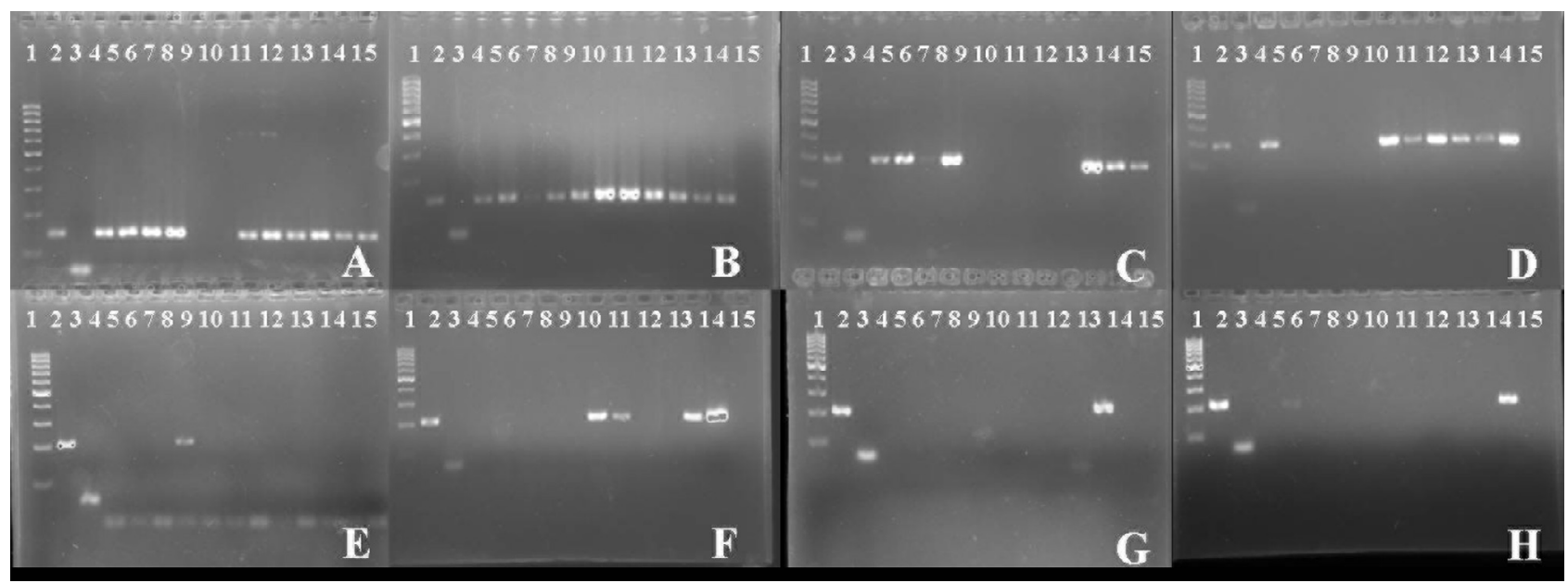

Figure 1. Results obtained in PCR following agarose gel electrophoresis. Lines: L1 100 bp ladder; L2 positive control; L3 negative control; L 4-15 samples. (A, B) E. acervulina 145 bp; (C, D) E. tenella 278 bp; (E, F) E. maxima 205 bp; (G, H) E. praecox 215 bp.

\section{DNA extraction}

DNA extraction from sporulated oocysts of each flock sample was performed with the commercial kit Isolate Fecal DNA Kit (Bioline; Cat. No. BIO-52038). We followed the manufacturer's instructions with minor modifications; we used $200 \mu \mathrm{L}$ of sporulated oocysts suspension, instead of $150 \mathrm{mg}$ faeces and the grinding time was $10 \mathrm{~min}$ instead of $1 \mathrm{~min}$. The kit contains for the first step of extraction tubes with beads (bashing bead lyses tube). The DNA was stored at $-20{ }^{\circ} \mathrm{C}$ till using.

\section{Polymerase chain reaction (PCR)}

Eimeria species were identified by single PCR assay using species-specific primers (Table 1) targeting the internal transcribed spacer-1 (ITS-1) as previously described by Schnitzler et al. [40, 41] and Haug et al. [15]. Each reaction mixture of $25 \mu \mathrm{L}$ contained: $2 \mu \mathrm{L}$ DNA sample; 25 pmol of species-specific reverse and forward primers; $12.5 \mu \mathrm{L}$ MyTaq $^{\mathrm{TM}}$ Mix (Bioline, Cat. No. BIO-25041); $9 \mu \mathrm{L}$ ultra-pure water (PCR Water, Cat. No. BIO-37080, Bioline); and $0.5 \mu \mathrm{L}$ of $1 \%$ bovine serum albumin. We used Houghton strains of all seven Eimeria species that infect chickens obtained from VLA (Veterinary Laboratory Agency Weybridge, UK) as positive controls, and distilled water as negative control.

The amplification was performed in MyGenie ${ }^{\mathrm{TM}} 96$ Gradient Thermal Block (Bioneer). The cycling parameters for the amplification were the following: an initial denaturation at $95{ }^{\circ} \mathrm{C}$ for $1 \mathrm{~min}$, followed by 35 cycles of denaturation $\left(95^{\circ} \mathrm{C}, 15 \mathrm{~s}\right)$, annealing $\left(58\right.$ or $\left.65^{\circ} \mathrm{C}, 15 \mathrm{~s}\right)$ and extension $\left(72{ }^{\circ} \mathrm{C}, 10 \mathrm{~s}\right)$, with a final extension at $72{ }^{\circ} \mathrm{C}$ for $3 \mathrm{~min}$.

The PCR products $(8 \mu \mathrm{L})$, mixed with loading buffer $(2 \mu \mathrm{L})$, were separated on a $1.5 \%$ agarose gel by electrophoresis, stained with SYBR ${ }^{\circledR}$ Green I Nucleic Acid Gel Stain (Invitrogen). Specific fragments were identified by size using a 100 bp ladder under UV light (BioDoc-It@ Imaging Systems, UVP®, VWR International LLC).

\section{Statistical analysis}

Data were statistically analysed with Epi Info version 3.5.2 [10]. First, the frequency and prevalence of species detected and the species combinations were recorded as overall, by farm type (small, medium and large farms) and type of coccidiostat used (ionophores, chemicals). Then, the difference in the prevalence was evaluated using Fisher exact test. A $p$ value of $<0.05$ was statistically significant.

\section{Results}

We found Eimeria spp. by PCR in 21 (91\%) out of 23 flocks, and in $11(92 \%)$ out of 12 farms. Four species of Eimeria were identified: E. acervulina, E. tenella, E. maxima and E. praecox (Figure 1). Overall, the most prevalent species was $E$. acervulina $(21 / 23 ; 91 \%)$, followed by E. tenella $(14 / 23 ; 61 \%)$ (Table 2). E. acervulina was overall significantly more prevalent in flocks with in-feed ionophores $(p<0.05)$. The overall prevalence of $E$. tenella was statistic significantly higher in small farms $(8 / 8 ; 100 \% ; p<0.05)$, and in flocks that received ionophores as anticoccidial feed additives $(p<0.01)$.

Infection with only one species ( $E$. acervulina) was detected in six $(26 \%)$ positive flocks; these flocks originated from large farms (Table 2). Mixed infections with two or more species were found in 15 (65\%) flocks (Table 2); the prevalence of mixed infections was significantly higher $(p<0.05)$ in small farms $(8 / 8 ; 100 \%)$, and in the farms where chickens received ionophores as anticoccidial feed additives (12/14; 86\%; $p<0.05)$, than in medium $(4 / 6 ; 67 \%)$ or large farms $(3 / 9$; $33 \%$ ), and those that received chemicals as anticoccidial feed additives $(1 / 5 ; 20 \%)$.

The most prevalent combinations were E. acervulina $+E$. tenella $(8 / 23 ; 35 \% ; p<0.05)$, and significantly more prevalent in small farms $(5 / 8 ; p<0.05)$ and in farms using ionophores $(8 /$ $14 ; 57 \% ; p<0.05)$ (Table 3). Four flocks $(17 \%)$ harboured mixed infection with E. acervulina + E. tenella + E. maxima. 
Table 3. Frequency and prevalence $[n(\%)]$ of mixed infections in broiler farms from Romania.

\begin{tabular}{|c|c|c|c|c|c|c|}
\hline & \multirow{2}{*}{$\begin{array}{c}\text { Total } \\
(n=23)\end{array}$} & \multicolumn{3}{|c|}{ Farm size } & \multicolumn{2}{|c|}{ Coccidiostat $^{\mathrm{a}}$} \\
\hline & & $\begin{array}{c}\text { Small } \\
(n=8)\end{array}$ & $\begin{array}{c}\text { Medium } \\
(n=6)\end{array}$ & $\begin{array}{l}\text { Large } \\
(n=9)\end{array}$ & $\begin{array}{l}\text { Ionophores } \\
(n=14)\end{array}$ & $\begin{array}{c}\text { Chemicals } \\
(n=5)\end{array}$ \\
\hline E. acervulina + E. tenella & $8(34,8)^{*}$ & $5(62,5)^{*}$ & $3(50,0)$ & 0 & $8(57,1)^{*}$ & 0 \\
\hline E. acervulina + E. praecox & $1(4,3)$ & 0 & 0 & $1(11,1)$ & 0 & $1(20,0)$ \\
\hline E. acervulina + E. tenella + E. maxima & $4(17,4)$ & $1(12,5)$ & $1(16,7)$ & $2(22,2)$ & $3(21,4)$ & 0 \\
\hline E. acervulina + E. tenella + E. praecox & $1(4,3)$ & $1(12,5)$ & 0 & 0 & $1(7,1)$ & 0 \\
\hline $\begin{array}{l}\text { E. acervulina }+ \text { E. tenella }+ \text { E. maxima }+E \text {. } \\
\text { praecox }\end{array}$ & $1(4,3)$ & $1(12,5)$ & 0 & 0 & 0 & 0 \\
\hline
\end{tabular}

Fisher exact test: ${ }^{*} p<0.05 ;{ }^{* *} p<0.01 ; * * * p 0.001{ }^{\text {a }}$ Nineteen out of 23 farmers answered to question regarding the coccidiostat used in-feed for coccidiosis control.

Other infection combinations found were: $E$. acervulina + E. praecox; E. acervulina $+E$. tenella + E. praecox; and E. acervulina + E. tenella + E. maxima + E. praecox.

\section{Discussion}

Epidemiological studies on the prevalence of Eimeria species are useful tools for prevention and control of coccidiosis $[31,34]$. Also, PCR-based assays can identify with accuracy species of Eimeria that afflict animals at farm level, even when they harbour mixed infections with a relative frequency down to $0.05 \%$ (two oocysts per PCR/4000) [17].

We identified species of Eimeria by PCR in 91\% (21/23) of samples, although by flotation oocysts have been seen in all samples $(23 / 23)$. In negative flocks to PCR there were few oocysts per gram faeces, between one and 117 (data not shown). Detection level by PCR is around 0.4-50 oocysts and depends mainly on sensitivity of the protocol used for DNA extraction [15]. Most of the protocols use glass beads in the first step of DNA extraction, and bead sizes and grinding times may influence the amount of DNA recovered from the sample [15]. Another cause can be the low number of oocysts per gram faeces in the samples. Haug et al. [15] found that when oocyst concentration is low, oocyst grinding is less efficient in extracting sample DNA.

We found that broiler chicken farms in Romania are populated with four species of Eimeria: E. acervulina, E. tenella, E. maxima and $E$. praecox. The most prevalent species were $E$. acervulina (91\%) and E. tenella (61\%). The crowding effect [51] and interactions among Eimeria species [50] are the most important factors affecting oocysts production. E. acervulina and E. tenella have the highest reproductive potential [51], and in mixed infections, E. acervulina reduces the oocysts production of E. brunetti, E. maxima, E. tenella and E. necatrix. We can suspect the same effect against E. praecox, because they occupy the same part of the gut. Besides, the crowding effect seems to be modulated by availability of epithelial cells and immunogenicity [51]. Immune response, developed after a primary infection, reduces the number of oocysts, and depends on immunogenicity of each Eimeria species. It is well known that E. maxima is the most immunogenic species in chickens, and E. acervulina and E. tenella have a moderate to low immunogenicity [29, 38]. Also, anticoccidial drugs interfere with the development of immunity in chickens. Broadly speaking, ionophores in low concentration stimulate the immune response, and in higher doses have immunosuppressive effect [33, 42]. Long et al. [28] found that monensin at $60-100 \mathrm{ppm}$ reduced the immune response to infection with Eimeria, while concentration of 40 and $50 \mathrm{ppm}$ allowed good development of immunity. Another ionophore, lasalocid, interferes partially with the development of immunity against E. tenella [39]. As regards chemicals, it was concluded that under experimental condition diclazuril did not significantly interfere with protective immunity formation against $E$. tenella [30]. As a conclusion, $\mathrm{Hu}$ et al. [18] found in a study using monensin, narasin, lasalocid, salinomycin, nicarbazin, halofuginone, robenidine, and amprolium and field isolates of Eimeria acervulina, E. maxima and E. tenella that none of the drugs interfered appreciably with protective immunity against Eimeria. Otherwise protection against infection with Eimeria is acquired gradually and it is complete at 7 weeks of age [7].

Haug et al. [16] found that long-term use of narasin between 2001 and 2004 conducted to a shift of coccidial population from a dominance of medium and large oocysts represented by E. tenella, E. praecox and E. maxima to a dominance of small oocysts as $E$. acervulina and an increase in flock prevalence. It is well known that long-term use of anticoccidials leads to development of drug resistance [6]. Drug resistance to anticoccidial drugs is described worldwide to all coccidiostats and to all Eimeria species [2, 21, 35, 36, 45, $53,57]$. Generally, E. acervulina seems to have a faster rate of drug resistance development and consequently a wide spectrum of resistance explained by its high reproductive index and the short life cycle $[5,20]$. This can be an explanation for preponderance of $E$. acervulina in our study, or even in others.

In Czechoslovakia, France and Sweden during 1990-1996, all seven species of Eimeria, occurring in mixed infections, were reported from broiler farms [23, 54]. After 2000, in Norway, E. acervulina $(100 \%)$, E. tenella $(77 \%)$ and E. maxima $(25 \%)$ were the predominant species as we report in our study, including low percentages of E. praecox $(10 \%)$ and E. necatrix (2\%) [17]. In North America, (Ontario, Canada), Ogedengbe et al. [34] found the same species as in European countries, but with a significantly lower prevalence between 0.3 and $2.5 \%$. Also, in a study with chickens raised on used litter in the USA, the predominant species were E. acervulina, E. maxima, E. praecox and E. tenella, according to Lee et al. [25]. In Africa, Middle East and Asia the most frequent species reported in broilers are E. brunetti (between 10 and 60\%) and E. necatrix 
(4-30\%) [1, 4, 24, 26, 44]. In the same geographical areas, E. tenella was the most prevalent species [4, 24], except in Iran where as in Europe, Australia and North America the most prevalent species was E. acervulina [44].

In the present study E. tenella was the second species found as the most prevalent overall, presenting the same statistical level $(p<0.01)$ of infection as E. acervulina in small and medium farms. However, E. tenella was less prevalent in large farms, and some authors reported that the flock size did not affect the prevalence [3]. E. tenella is one of the most pathogenic species. It causes caecal lesions as haemorrhages, oedema, necrosis and anaemia [19]. Moreover, in an experiment it was observed that $E$. tenella infection can be a cause of the recrudescence of Salmonella enteritidis [37].

Multiple infections with different species of Eimeria in chickens are a common situation in most of the farms $[1,17$, 54]. We found mixed infection (2-4 species) in $65 \%$ of the cases and single infection (E. acervulina) in $22 \%$ of the cases. Single infection was observed only in large farms (75\%) and was more prevalent than mixed infections (38\%) in these farms. Haug et al. [17] found single infection with E. acervulina $(16 \%)$ less prevalent in Norway than in our study in Romania. Mixed infections were associated with small and medium farms and with ionophores. The same findings were observed in China, Shandong province, in small-scale farms where more than one Eimeria species existed in most of the samples [47]. Most likely, the mixed infections are more prevalent in small and medium farms due to poor management and biosecurity practises as high stocking densities, reduced time between successive grow-outs [26], microclimate and workers [22]. As regarding ionophores (alter ion transport and disrupt osmotic balance), they do not prevent replication of Eimeria completely [9] as chemicals do (affect parasite metabolism). In order to prevent drug resistance, rotation of coccidiostats and shuttle programmes are recommended. Nevertheless, drug resistance is widespread and it was described to all coccidiostats and Eimeria species [8, 35]. Small and medium farms in Romania do not have their own feed mill and in most cases they cannot control the prophylaxis programme (personal observation).

The high prevalence of infection with $E$. acervulina and $E$. tenella as single or multiple infections in Romanian broiler farms can be due to reduced susceptibility to anticoccidial drugs and to poor management practises, especially in small and medium farms. Further investigations are needed in order to determine the susceptibility of these strains to coccidiostats. Our results are the first to report the prevalence of Eimeria species based on molecular analysis.

Acknowledgements. This work was supported by grants of the Romanian National Authority for Scientific Research, CNCSIS-UEFISCSU (CNDI-UEFISCDI), project number PNII-RU-PD 188/ 2010 (code PD 257). PCR was done with equipment purchased through the projects CEEX Module I 99/2006, CEEX Module II 5926/2006 and PNII 182/CPI/2008 financed by the Ministry of Education and Research from Romania.

We thank Ralph Marshall (VLA, UK) for supplying strains of Eimeria species and to Jorge F.S. Ferreira for English assistance and suggestions.

\section{References}

1. Aarthi S, Dhinakar RG, Raman M, Gomathinayagam S, Kumanan K. 2010. Molecular prevalence and preponderance of Eimeria spp among chickens in Tamil Nadu India. Parasitology Research, 107(4), 1013-1017.

2. Abbas RZ, Iqbal Z, Sindhu ZD, Khan MN, Arshad M. 2008. Identification of cross-resistance and multiple resistance in Eimeria tenella field isolates to commonly used anticoccidials in Pakistan. Journal of Applied Poultry Research, 17, 361-368.

3. Al-Natour MQ, Suleiman MM, Abo-Shehada MN. 2002. Flocklevel prevalence of Eimeria species among broiler chicks in northern Jordan. Preventive Veterinary Medicine, 53(4), 305310.

4. Awais MM, Akhtar M, Iqbal Z, Muhammad F, Anwar MI. 2012. Seasonal prevalence of coccidiosis in industrial broiler chickens in Faisalabad Punjab Pakistan. Tropical Animal Health and Production, 44(2), 323-328.

5. Chapman HD. 1976. Resistance of field isolates of Eimeria species to anticoccidial drugs. Avian Pathology, 5(4), 283-290.

6. Chapman HD. 1997. Biochemical, genetic and applied aspects of drug resistance in Eimeria parasites of the fowl. Avian Pathology, 26, 221-244.

7. Chapman HD. 1999. Anticoccidial drugs and their effects upon the development of immunity to Eimeria infections in poultry. Avian Pathology, 28, 521-535.

8. Chapman HD, Shirley MW. 1989. Sensitivity of field isolates of Eimeria species to monensin and lasalocid in the chicken. Research in Veterinary Science, 46(1), 114-117.

9. Chapman HD, Johnson ZB. 1992. Oocysts of Eimeria in the litter of broilers reared to eight weeks of age before and after withdrawal of lasalocid or salinomycin. Poultry Science, 71(8), 1342-1347.

10. Centers for Disease Control and Prevention in Atlanta, Georgia, USA. Epi Info Version 3.5.2. http://wwwn.cdc.gov/epiinfo/7/ index.htm. December 17, 2010.

11. Dalloul RA, Lillehoj HS. 2006. Poultry coccidiosis: recent advancements in control measures and vaccine development. Expert Review of Vaccines, 5, 143-163.

12. Fernandez S, Katsuyama AM, Kashiwabara AY, Madeira AM, Durham AM, Gruber A. 2004. Characterization of SCAR markers of Eimeria spp of domestic fowl and construction of a public relational database (The Eimeria SCARdb). FEMS Microbiology Letters, 238, 183-188.

13. Gasser RB, Woods WG, Wood JM, Ashdown L, Richards G, Whithear KG. 2001. Automated fluorescence-based approach for the specific diagnosis of chicken coccidiosis. Electrophoresis, 22, 3546-3550.

14. Hadipour MM, Olyaie A, Naderi M, Azad F, Nekouie O. 2011. Prevalence of Eimeria species in scavenging native chickens of Shiraz Iran. African Journal of Microbiology Research, 5(20), 3296-3299.

15. Haug A, Thebo P, Mattsson JG. 2007. A simplified protocol for molecular identification of Eimeria species in field samples. Veterinary Parasitology, 146(1-2), 35-45.

16. Haug A, Gjevre AG, Skjerve E, Kaldhusdal M. 2008. A survey of the economic impact of subclinical Eimeria infections in broiler chickens in Norway. Avian Pathology, 37(3), 333-341. 
17. Haug A, Gjevre AG, Thebo P, Mattsson JG, Kaldhusdal M. 2008. Coccidial infections in commercial broilers: epidemiological aspects and comparison of Eimeria species identification by morphometric and polymerase chain reaction techniques. Avian Pathology, 37(2), 161-170.

18. Hu J, Fuller L, McDougald LR. 2000. Do anticoccidials interfere with development of protective immunity against coccidiosis in broilers? Journal of Applied Poultry Research, 9(3), 352-358.

19. Iacob OC, Duma V. 2009. Clinical paraclinical and morphopathological aspects in cecal eimeriosis of broilers. Scientia Parasitologica, 10, 43-50.

20. Jeffers TK. 1974. Anticoccidial drug resistance: Differences between Eimeria acervulina and E. tenella strains within broiler houses. Poultry Science, 53, 1009-1013.

21. Kawazoe U, Fabio JD. 1994. Resistance to diclazuril in field isolates of Eimeria species obtained from commercial broiler flocks in Brazil. Avian Pathology, 23, 305-311.

22. Kiani R, Rasadi M, Mohammadian MN. 2007. Sources and routes of introduction of Eimeria oocysts into broiler chick's houses. International Journal of Poultry Science, 6(12), 925927.

23. Kučera J. 1990. Identification of Eimeria species in Czechoslovakia. Avian Pathology, 19, 59-66.

24. Lee BH, Kim WH, Jeong J, Yoo J, Kwon YK, Jung BY, Kwon JH, Lillehoj HS, Min W. 2010. Prevalence and cross-immunity of Eimeria species on Korean chicken farms. Journal of Veterinary Medical Science, 72(8), 985-989.

25. Lee KW, Lillehoj HS, Jang SI, Pagès M, Bautista DA, Pope CR, Ritter GD, Lillehoj EP, Neumann AP, Siragusa GR. 2012. Effects of in ovo vaccination and anticoccidials on the distribution of Eimeria spp in poultry litter and serum antibody titers against coccidia in broiler chickens raised on the used litters. Research in Veterinary Science, 93(1), 177-182.

26. Lobago F, Worku N, Wossene A. 2005. Study on coccidiosis in Kombolcha poultry farm Ethiopia. Tropical Animal Health and Production, 37(3), 245-251.

27. Long PL, Joyner LP. 1984. Problems in the identification of species of Eimeria. Journal of Parasitology, 31(4), 535-541.

28. Long PL, Millard BJ, Smith KM. 1979. The effect of some anticoccidial drugs on the development of immunity to coccidiosis in field and laboratory conditions. Avian Pathology, 8(4), 453-467.

29. Long PL, Johnson J, McKenzie ME, Perry E, Crane MS, Murray PK. 1986. Immunisation of young broiler chickens with low level infections of Eimeria tenella, E. acervulina or E. maxima. Avian Pathology, 15(2), 271-278.

30. Maes L, Vanparijs O, Marsboom R. 1991. Effect of diclazuril (Clinacox) on the development of protective immunity against Eimeria tenella: laboratory trial in broiler chickens. Poultry Science, 70(3), 504-508.

31. Morris GM, Gasser RB. 2006. Biotechnological advances in the diagnosis of avian coccidiosis and the analysis of genetic variation in Eimeria. Biotechnology Advances, 24(6), 590-603.

32. Morris GM, Woods WG, Richards DG, Gasser RB. 2007. Investigating a persistent coccidiosis problem on a commercial broiler-breeder farm utilising PCR-coupled capillary electrophoresis. Parasitology Research, 101(3), 583-589.

33. Munir K, Muneer MA, Tiwari A, Chaudhry RM, Muruganandan S. 2007. Effects of polyether ionophores on the protective immune responses of broiler chickens against Angara disease and Newcastle disease viruses. Veterinary Research Communications, 31(7), 909-929.

34. Ogedengbe JD, Hunter DB, Barta JR. 2011. Molecular identification of Eimeria species infecting market-age meat chickens in commercial flocks in Ontario. Veterinary Parasitology, 178(3-4), 350-354.

35. Peek HW, Landman WJ. 2003. Resistance to anticoccidial drugs of Dutch avian Eimeria spp field isolates originating from 1996, 1999 and 2001. Avian Pathology, 32(4), 391-401.

36. Peeters JE, Derijcke J, Verlinden M, Wyffels R. 1994. Sensitivity of avian Eimeria spp to seven chemical and five ionophore anticoccidials in five Belgian integrated broiler operations. Avian Diseases, 38, 483-493.

37. Qin ZR, Arakawa A, Baba E, Fukata T, Miyamoto T, Sasai K, Withanage GS. 1995. Eimeria tenella infection induces recrudescence of previous Salmonella enteritidis infection in chickens. Poultry Science, 74(11), 1786-1792.

38. Rose ME, Long PL. 1962. Immunity to four species of Eimeria in fowls. Immunology, 5, 79-92.

39. Sasmal NK, Sinha PK, Senapati PK, Bhowmik MK. 1984. Acquired immunity to Eimeria tenella in lasalocid-treated chickens. Veterinary Parasitology, 15(1), 1-9.

40. Schnitzler BE, Thebo PL, Mattsson JG, Tomley FM, Shirley MW. 1998. Development of a diagnostic PCR assay for the detection and discrimination of four pathogenic Eimeria species of the chicken. Avian Pathology, 27, 490-497.

41. Schnitzler BE, Thebo PL, Tomley FM, Uggla A, Shirley MW. 1999. PCR identification of chicken Eimeria: a simplified readout. Avian Pathology, 28(1), 89-93.

42. Shalaby MA, El-Sanousi AA, Yehia MM, Naser A, Reda IM. 1993. The effect of salinomycin on the immune response of chicks. Deutsche tierarztliche Wochenschrift, 100(5), 182-185.

43. Shirley MV. 1995. Eimeria species and strains, in Guidelines on Techniques in Coccidiosis, Eckert J, Braun R, Shirley MW, Coudert P, (Eds.) COST89/820 Biotechnology, Research European Commission, Luxembourg, p. 1-25.

44. Shirzad MR, Seifi S, Gheisari HR, Hachesoo BA, Habibi H, Bujmehrani H. 2011. Prevalence and risk factors for subclinical coccidiosis in broiler chicken farms in Mazandaran province Iran. Tropical Animal Health and Production, 43(8), 16011604.

45. Stephen B, Rommel M, Daugschies A, Haberkorn A. 1997. Studies of resistance to anticoccidials in Eimeria field isolates and pure Eimeria strains. Veterinary Parasitology, 69, 19-29.

46. Stucki U, Braun R, Roditi I. 1993. Eimeria tenella: characterization of a $5 \mathrm{~S}$ ribosomal RNA repeat unit and its use as a species-specific probe. Experimental Parasitology, 76, 68-75.

47. Sun XM, Pang M, Jia T, Yan WC, He G, Hao LL, Bentue M, Sue X. 2009. Prevalence of Eimeria species in broilers with subclinical signs from fifty farms. Avian Diseases, 53, 301-305.

48. Tsuji N, Kawazu S, Ohta M, Kamio T, Isobe T, Shimura K, Fujisaki K. 1997. Discrimination of eight chicken Eimeria species using the two-step polymerase chain reaction. Journal of Parasitology, 83, 966-970.

49. Uniunea crescatorilor de pasari din Romania (Romanian Association of Poultry Breeders). 2013. http://www.avicultura.ro/, consulted on November 27, 2012.

50. Williams RB. 1973. The effect of Eimeria acervulina on the reproductive potentials of four other species of chicken coccidia during concurrent infections. British Veterinary Journal, 129(3), xxix-xxxi. 
51. Williams RB. 2001. Quantification of the crowding effect during infections with the seven Eimeria species of the domesticated fowl: its importance for experimental designs and the production of oocyst stocks. International Journal of Parasitology, 31(10), 1056-1069.

52. Williams RB. 2005. Intercurrent coccidiosis and necrotic enteritis of chickens: rational integrated disease management by maintenance of gut integrity. Avian Pathology, 34(3), 159180 .

53. Williams RB. 2006. Tracing the emergence of drug-resistance in coccidia (Eimeria spp) of commercial broiler flocks medicated with decoquinate for the first time in the United Kingdom. Veterinary Parasitology, 135, 1-14.

54. Williams RB, Bushell AC, Reperant JM, Doy TG, Morgan JH, Shirley MW, Yvore P, Carr MM, Fremont Y. 1996. A survey of
Eimeria species in commercially-reared chickens in France during 1994. Avian Pathology, 25(1), 113-130.

55. Williams RB, Marshall RN, La Ragione RM, Catchpole J. 2003. A new method for the experimental production of necrotic enteritis and its use for studies on the relationships between necrotic enteritis coccidiosis and anticoccidial vaccination of chickens. Parasitology Research, 90(1), 19-26.

56. Williams RB, Marshall RN, Pagés M, Dardi M, del Cacho E. 2009. Pathogenesis of Eimeria praecox in chickens: virulence of field strains compared with laboratory strains of E. praecox and Eimeria acervulina. Avian Pathology, 38(5), 359-366.

57. Zhang JJ, Wang LX, Ruan WK, An J. 2013. Investigation into the prevalence of coccidiosis and maduramycin drug resistance in chickens in China. Veterinary Parasitology, 191, 29-34.

Cite this article as: Györke A, Pop L \& Cozma V: Prevalence and distribution of Eimeria species in broiler chicken farms of different capacities. Parasite, 2013, 20, 50.

\section{OP PARASTE}

An international open-access, peer-reviewed, online journal publishing high quality papers on all aspects of human and animal parasitology

Reviews, articles and short notes may be submitted. Fields include, but are not limited to: general, medical and veterinary parasitology; morphology, including ultrastructure; parasite systematics, including entomology, acarology, helminthology and protistology, and molecular analyses; molecular biology and biochemistry; immunology of parasitic diseases; host-parasite relationships; ecology and life history of parasites; epidemiology; therapeutics; new diagnostic tools.

All papers in Parasite are published in English. Manuscripts should have a broad interest and must not have been published or submitted elsewhere. No limit is imposed on the length of manuscripts.

Parasite (open-access) continues Parasite (print and online editions, 1994-2012) and Annales de Parasitologie Humaine et Comparée (1923-1993) and is the official journal of the Société Française de Parasitologie. 